University of Nebraska - Lincoln

DigitalCommons@University of Nebraska - Lincoln

Papers in Biotechnology

Chemical and Biomolecular Engineering

Research and Publications

October 2000

\title{
Modeling Pichia pastoris Growth on Methanol and Optimizing the Production of a Recombinant Protein, the Heavy-Chain Fragment C of Botulinum Neurotoxin, Serotype A
}

\author{
Wenhui Zhang \\ Biological Process Development Facility, Department of Food Science and Technology, University of \\ Nebraska-Lincoln, Lincoln, Nebraska \\ Mark A. Bevins \\ Biological Process Development Facility, Department of Food Science and Technology, University of \\ Nebraska-Lincoln, Lincoln, Nebraska \\ Bradley A. Plantz \\ Biological Process Development Facility, Department of Food Science and Technology, University of \\ Nebraska-Lincoln, Lincoln, Nebraska \\ Leonard A. Smith \\ United States Army Medical Research Institute of Infectious Diseases (USAMRIID), Fort Detrick, Frederick, \\ Maryland 21702-5012 \\ Michael M. Meagher \\ Department of Chemical Engineering, University of Nebraska-Lincoln, mmeagher@unl.edu \\ Follow this and additional works at: https://digitalcommons.unl.edu/chemeng_biotechnology \\ Part of the Biochemical and Biomolecular Engineering Commons
}

Zhang, Wenhui ; Bevins, Mark A.; Plantz, Bradley A.; Smith, Leonard A.; and Meagher, Michael M., "Modeling Pichia pastoris Growth on Methanol and Optimizing the Production of a Recombinant Protein, the Heavy-Chain Fragment C of Botulinum Neurotoxin, Serotype A" (2000). Papers in Biotechnology. 18. https://digitalcommons.unl.edu/chemeng_biotechnology/18

This Article is brought to you for free and open access by the Chemical and Biomolecular Engineering Research and Publications at DigitalCommons@University of Nebraska - Lincoln. It has been accepted for inclusion in Papers in Biotechnology by an authorized administrator of DigitalCommons@University of Nebraska - Lincoln. 
Abstract: An unstructured growth model for the recombinant methylotrophic yeast $P$. pastoris Mut expressing the heavy-chain fragment $C$ of botulinum neurotoxin serotype $A$ [BoNT/A $\left.\left(H_{c}\right)\right]$, was successfully established in quasi-steady state fed-batch fermentations with varying cell densities. The model describes the relationships between specific growth rate and methanol concentration, and the relationships between specific methanol and ammonium consumption rates and specific growth rate under methanol-limited growth conditions. The maximum specific growth rate $(\mu)$ determined from the model was $0.08 \mathrm{~h}_{-1}$ at a methanol concentration of $3.65 \mathrm{~g} / \mathrm{L}$, while the actual maximum $\mu$ was 0.0709 $\mathrm{h}_{-1}$. The maximum specific methanol consumption rate was 0.0682 $\mathrm{g} / \mathrm{g} \mathrm{WCW} / \mathrm{h}$. From the model, growth can be defined as either methanol-limited or methanol-inhibited and is delineated at a methanol concentration of $3.65 \mathrm{~g} / \mathrm{L}$. Under inhibited conditions, the observed biomass yield $(\mathrm{Y} \times \mathrm{MeOH})$ was lower and the maintenance coefficient $(\mathrm{mMeOH})$ was higher than compared to limited methanol conditions. The $\mathrm{Y} \times \mathrm{MeOH}$ decreased and $\mathrm{mmeOH}$ increased with increasing methanol concentration under methanolinhibited conditions. BoNT/A $\left(\mathrm{H}_{\mathrm{c}}\right)$ content in cells (a) under inhibited growth was lower than that under limited growth, and decreased with increasing methanol concentration. A maximum a of $1.72 \mathrm{mg} / \mathrm{g}$ WCW was achieved at a $\mu$ of $0.0267 \mathrm{~h}_{-1}$ and induction time of $12 \mathrm{~h}$.

Keywords: Pichia pastoris; fed-batch; growth modeling; optimization; fermentation; botulinum neurotoxin

\section{INTRODUCTION}

The Pichia pastoris expression system has been used extensively for the production of heterologous proteins. The advantages of this system include high cell densities on a defined minimal basal salts medium (Brierley et al., 1990; Cregg and Higgins, 1995), efficient post-translational modifications (Digan et al., 1988; Tschopp et al., 1987), less secretion of endogenous proteins while expressing secreted recombinant protein (Digan et al., 1988; Laroche et al., 1994; Tschopp et al., 1987), and a strong, well-regulated methanolinduced promoter (Cregg and Madden, 1988; Cregg and Vedvick, 1993). It is known that $P$. pastoris can assimilate methanol but cannot tolerate high methanol concentrations. This is due to the accumulation of formaldehyde and hydrogen peroxide inside the cells, both of which are the oxidized products of methanol by the alcohol oxidase and are toxic to the cell (Couderc and Baratti, 1980; Cregg and Madden, 1988; Van der Klei et al., 1990). In order to obtain high cell densities while maintaining a low level of methanol, a fed-batch strategy is commonly used. The methanol feeding strategy, which also dictates the specific growth rate, is one of the most important factors for maximizing recombinant protein production, since all of the biochemical reactions for product formation are directly or indirectly associated with cell growth (Shioya, 1992). The methanol feeding strategy used by most researchers for methanol utilization positive (Mut+) recombinant $P$. pastoris fed-batch fermentation is from "Pichia Fermentation Process Guidelines" of Invitrogen Co. (San Diego, CA). There are two different empirical feeding strategies that are commonly used (Stratton et al., 1998). The first is the dissolved oxygen (D.O.) spike method, where during methanol induction the methanol feed pump is stopped and the amount of time is recorded for the D.O. to increase $10 \%$ (a limited culture will have D.O. spike times of 15-30 s). The second method uses preprogrammed linear feed rates that typically do not exceed $11 \mathrm{~mL} / \mathrm{L} / \mathrm{h}$. Both protocols are designed to maintain a residual methanol concentration of nearly $0 \mathrm{~g} / \mathrm{L}$, which is not necessarily optimum for maximum protein production. Some protocols for regulating methanol feed rate were reported in the production of bovine lysozyme (Brierley et al., 1990), but the effect of methanol feed rate on the protein production was not detailed. Shake flask cultures with methanol maintained at $0.3 \% \mathrm{v} / \mathrm{v}$ were studied by using a methanol sensor (Guarna et al., 1997). The results showed the volumetric protein productivity, while maintaining a constant methanol level, increased 5-fold over cultures that were not maintained with constant methanol. Because the specific growth rate and specific production rate were not compared, it is hard to conclude if the methanol affected the protein production rate. The specific growth rate and specific protein production rate were determined with methanol concentrations ranging between 1.5 and $31 \mathrm{~g} / \mathrm{L}$ (Katakura et al., 1998), but the study did not extend to methanol-limited growth or develop a growth model. The purpose of this research is to establish an unstructured growth model for $P$. pastoris Mut+and use the model to optimize the production of a recombinant protein, the heavy-chain fragment $\mathrm{C}$ of botulinum neurotoxin, serotype A $\left[\mathrm{BoNT} / \mathrm{A}\left(\mathrm{H}_{\mathrm{c}}\right)\right]$. The botulinum neurotoxin is produced by Clostridium botulinum under anaerobic conditions and is classified into seven serotypes designated types A through G. It is the most potent toxin known to science (Lamanna, 1959). BoNTA $/\left(\mathrm{Hc}_{\mathrm{c}}\right)$, the $50-\mathrm{kDa}$ carboxyl-terminal region of the botulinum neurotoxin, is involved in the recognition of specific ectoreceptors on peripheral cholinergic nerve cells. The toxin fragment is nontoxic and has been shown to elicit significant protective immunity in mice and is a vaccine candidate (Byrne et al., 1998; Clayton et al., 1995).

\section{MATERIALS AND METHODS}

\section{Experimental Setup}

Fermentations were performed with a 5-L Bioflo 3000 fermentor interfaced with the computer-based software, AFSBioCommand, for data acquisition and supervisory control (New Brunswick $\mathrm{Sic}$ entific Co., Edison, GA). A part of the off-gas was diverted to an MC-168 methanol monitor and controller (PTI Instruments, Inc., Kathleen, GA) equipped with a TGS822 methanol sensor (Figaro Engineering Inc., Osaka, Japan), which were used to maintain a constant level of methanol in the broth. A methanol feed pump (Model 101U/R, Watson-Marlow Ltd., England), balance (Model PR1203, Mettler Toledo, Switzerland), and the MC-168 controller were interfaced with the AFS-BioCommand to make a closed-loop control system, Fig. 1. The D.O. was set to $20 \%$ and controlled by an agitation $/ \mathrm{O}_{2}$ cascade available as part of the BioFlo 3000 system. Pure oxygen was supplied as needed to maintain $20 \%$ of D.O. saturation.

\section{Strain and Inoculum Preparation}

P. pastoris GS115 Mut+, expressing the $\operatorname{BoNT} / \mathrm{A}\left(\mathrm{H}_{\mathrm{c}}\right)$ fragmentintracellularly, is described elsewhere (Byrne et al., 1998). Attempts were made to secrete the $\left.\operatorname{BoNT} / \mathrm{A}_{(\mathrm{H}}\right)$ fragment, but the fragment was glycosylated, which rendered the fragment immunologically inactive. The native toxin is not glycosylated. The gene was determined to be stable after a minimum of 25 generations (data not shown). Individual fermentors were inoculated with $40 \mathrm{~mL}$ of freshly thawed starter culture. These cultures were prepared by inoculating $200 \mathrm{~mL}$ of BMGY (buffered minimal glycerol complex medium, Pichia Expression Kit, Invitrogen Co.) containing $10 \mathrm{~g} / \mathrm{L}$ glycerol in a $2-\mathrm{L}$ baffled shake flask with $1 \mathrm{~mL}$ of a stock culture maintained frozen in liquid nitrogen (vapor phase). The culture was incubated at $30^{\circ} \mathrm{C}$ with 200-rpm shaking rate until an OD600 (optical density at $600 \mathrm{~nm}$ ) between 2 and 6 was reached. The entire $200 \mathrm{~mL}$ was aseptically 
transferred to a 5-L fermentor containing $4 \mathrm{~L}$ of BMGY with 40 $\mathrm{g} / \mathrm{L}$ glycerol. When the density reached an OD 600 of 50 , the cells were harvested aseptically using sterile $500-\mathrm{mL}$ centrifuge bottles and centrifuged at $2000 \mathrm{~g}$. The pellets were resuspended in $1 \mathrm{~L}$ of sterilized BMGY containing $150 \mathrm{~g} / \mathrm{L}$ glycerol. Cell suspension aliquots of $40 \mathrm{~mL}$ (approximately 200 OD600) were dispensed into $50-\mathrm{mL}$ sterile conical tubes and stored at $-80^{\circ} \mathrm{C}$ until ready for use.

\section{Fermentation}

\section{Glycerol Batch Phase}

The batch phase was $2 \mathrm{~L}$ of basal salts medium (BSM), which, per

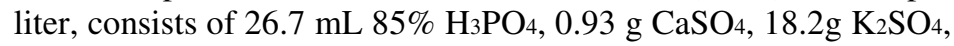
$14.9 \mathrm{~g} \mathrm{MgSO}_{4}$ ? $7 \mathrm{H}_{2} \mathrm{O}, 4.13 \mathrm{~g} \mathrm{KOH}$, and $40.0 \mathrm{~g}$ glycerol. Prior to inoculation, the $\mathrm{pH}$ was adjusted to 5.0 with concentrated ammonium hydroxide followed by the addition of $8.7 \mathrm{~mL}$ of PTM1 trace salts (containing, per liter, $6.0 \mathrm{~g} \mathrm{CuSO}_{4}$ ? $5 \mathrm{H}_{2} \mathrm{O}, 0.08$ g NaI, 3.0 g MnSO 4 ? $\mathrm{H}_{2} \mathrm{O}, 0.2 \mathrm{~g} \mathrm{Na}_{2} \mathrm{MoO}_{4}$ ? 2 $\mathrm{H}_{2} \mathrm{O}, 0.02 \mathrm{~g} \mathrm{H}_{3} \mathrm{BO}_{3}$, $0.5 \mathrm{~g} \mathrm{CoCl}_{2}, 20.0 \mathrm{~g} \mathrm{ZnCl}_{2}, 65.0 \mathrm{~g} \mathrm{FeSO}_{4}$ ? $7 \mathrm{H}_{2} \mathrm{O}, 0.2 \mathrm{~g}$ biotin, and $\left.5.0 \mathrm{~mL} \mathrm{H}_{2} \mathrm{SO}_{4}\right)$. Batch phase conditions were tempera ture, $30^{\circ} \mathrm{C}$; $\mathrm{pH}, 5.0$ (controlled with concentrated ammonium hydroxide); and D.O., 20\%. These variables were monitored and maintained continuously by the fermentation unit. The end of batch phase was indicated by a spike in the D.O. caused by the exhaustion of glycerol. The cell mass at the end of the batch phase was approximately $100 \mathrm{~g} / \mathrm{L}$ wet cells.

\section{Glycerol Fed-Batch Phase and Transition Phase}

The fed-batch phase was performed under glycerol-limited conditions to increase cell mass and prepare the cells for induction. Limited feed benefits the induction of the AOX1(alcohol oxidase) promoter by facilitating the consumption of metabolites, such as acetate and ethanol, which build up during the batch phase and are inhibitory to AOX1 induction. The suggested minimum length of time for the fedbatch phase is $1 \mathrm{~h}$. Longer times and/or higher feed rates may be used to increase cell mass prior to induction. For this project a 1-h fed-batch period was used at a feed rate of $20 \mathrm{~g} \mathrm{50 \%}$ w/w glycerol (containing $12 \mathrm{~mL}$ of PTM1 per liter) per hour per liter of broth. Following the fed-batch phase, a transition phase was designed to shorten the time required for the cells to fully adapt to methanol. The transition phase is initiated by the addition of 1.5 $\mathrm{g} / \mathrm{L}$ methanol, which initiates induction. The glycerol feed rate is simultaneously set to ramp down linearly from $20 \mathrm{~g} / \mathrm{L} / \mathrm{h}$ to 0 over a 3-h period. During the first hour, the cells continued to utilize glycerol as the primary carbon and energy source, which was confirmed by off-gas analysis. After the first hour the methanol concentration was observed to decrease quickly until by the end of the second hour the detection limit of the methanol sensor was reached. These two hours were defined as the transition phase, during which the cells initiated the switch from glycerol to meth nol. By the end of the transition phase the cells were fully adapted to methanol, which was confirmed by a sharp drop in the D.O. when the methanol feeding profile was initiated. This twohour adaptation time compares to a period of $4-5 \mathrm{~h}$ when using the traditional method of complete glycerol exhaustion followed by a very low methanol feed (Stratton et al., 1998).

Methanol Fed-Batch Phase
Once the cells were fully transitioned, the methanol (containing 12 $\mathrm{mL}$ of PTM1 per liter) was fed to start the methanol fed-batch phase (production phase). Two feeding strategies were investigated. The first was a methanol-excess feed strategy in which the methanol concentration was controlled at set levels between 2.0 and $30.0 \mathrm{~g} / \mathrm{L}$ to study the effects of excess methanol on growth and protein production. The rate of increasing the methanol concentration was limited to $10 \mathrm{~g} / \mathrm{L} / \mathrm{h}$ to prevent the cells from being shocked. This strategy allowed the maximum specific growth rate,

$\mu \mathrm{m}$, to be determined. The second strategy controlled the growth rate below $\mu \mathrm{m}$ by methanol-limited feeding. The specific growth rate was kept at desired values by controlling the methanol feed rate at an exponential increase, which allowed the growth, production, and substrate consumption rates to be determined.

\section{Analytical Methods}

Cell density was expressed as wet cell weight (WCW), which was measured by removing duplicate $10-\mathrm{mL}$ aliquots of the fermentation broth into preweighed $15-\mathrm{mL}$ conical tubes. The samples were centrifuged at $2000 \mathrm{~g}$, the supernatants were decanted, and the pellets were weighed. One gram of wet cells is equivalent to approximately $0.28 \mathrm{~g}$ dry cell weight. The off-line methanol concentration was determined by gas chromatography (GC-17A, Shimadzu Co., Columbia, MD) with isopropyl alcohol as an internal standard. Cell were disrupted as a $150 \mathrm{~g} \mathrm{WCW} / \mathrm{L}$ suspension of cells in lysis buffer [2.92 g NaCl, $1.86 \mathrm{~g}$ EDTA, 10.47 g MOPS, sodium (Calbiochem Co., San Diego, CA), $2.5 \mathrm{~g}$ CHAPS (Pierce Co., Rockford, IL), in $1 \mathrm{~L} \mathrm{ddH}_{2} \mathrm{O}$, pH to 7.5 with $\mathrm{NaOH}$. Aliquots of $1 \mathrm{~mL}$ were mixed with approximately $2.2 \mathrm{~g}$ zirconia/silica beads (Biospec Products, Inc. Bartlesville, OK) in 2.0-mL screw-cap tubes followed by disruption at $4{ }^{\circ} \mathrm{C}$ with a vibrating disrupter (Mini-BeadBeater-8, Biospec Products, Inc.) for 8 cycles ( 1 min vibrating and $4 \mathrm{~min}$ resting in each cycle). The lysate/bead mixture was centrifuged until the supernatant was clear, and $100 \mu \mathrm{L}$ aliquots were diluted 20-fold with lysis buffer containing $0.5 \mathrm{~g} / \mathrm{L}$ CHAPS and then stored frozen at $-20^{\circ} \mathrm{C}$ until analyzed for BoNT/A $\left(\mathrm{H}_{c}\right)$. BoNT/A $\left(\mathrm{H}_{\mathrm{c}}\right)$ was determined by using a modified ELISA procedure (Byrne et al., 1998). All incubations were completed at $37^{\circ} \mathrm{C}$ with sealed plate covers unless indicated differently. Microtiter plates (Immulon 4HBX; Dynex Technologies Inc., Chantilly, VA) were incubated overnight at $4{ }^{\circ} \mathrm{C}$ with $100 \mu \mathrm{L}$ per well of coating monoclonal antibody 5BA2 (Hallis et al., 1993) at $0.5 \mu \mathrm{g} / \mathrm{mL}$ in $100 \mu \mathrm{mM}$ sodium carbonate buffer, $\mathrm{pH}$ 9.6 (SCB). The plates were then blocked for $2 \mathrm{~h}$ with $5 \% \mathrm{w} / \mathrm{v}$ nonfat dry milk in SCB. The plates were washed with SCB followed by the addition of $100 \mu \mathrm{L}$ of either sample or standard to each well and were then incubated for $90 \mathrm{~min}$. Lysate samples were diluted 1/1000 to $1 / 2000$ in SCB which contained 5\% w/v nonfat dry milk and $0.05 \%$ w/v CHAPS before addition to the plates. The plates were washed with SCB then incubated for $1 \mathrm{~h}$ after the addition of $100 \mu \mathrm{L}$ per well of buffered affinity-purified horse anti-BoNT/A $\left(\mathrm{H}_{\mathrm{c}}\right)$ at $2.0 \mu \mathrm{g} / \mathrm{mL}$ in $5 \% \mathrm{w} / \mathrm{v}$ nonfat dry milk in phosphate-buffered saline with $0.05 \% \mathrm{w} / \mathrm{v}$ Tween 20 (PBS-T). The wash solution was changed to PBS-T. The plates were washed and incubated for $1 \mathrm{~h}$ with $100 \mu \mathrm{L}$ per well of peroxidase-labeled goat anti-horse $\operatorname{IgG}[\mathrm{H}+\mathrm{L}]$ (Kirkegaard \& Perry Laboratories, Gaithersburg, MD) at $2.0 \mu \mathrm{g} / \mathrm{mL}$ in $5 \% \mathrm{w} / \mathrm{v}$ nonfat dry milk in PBS-T. The plates were washed again and $100 \mu \mathrm{L}$ of ABTS [2,28azinobis(3-ethlybenzthiazoline-6-sulfonic acid)] peroxidase substrate (Kirkegaard \& Perry Laboratoies, Gaithersburg, MD) 
was added to each well followed immediately by incubation at room temperature (for 10-30 min) until the $A 405$ of the highest standard was near 2. The reaction was stopped by addition of 100 $\mu \mathrm{L}$ of $2 \%$ w/v oxalic acid in water. The $A 405$ was read with a MRX microplate reader (Dynex Technologies Inc.).

\section{Calculation of the Specific Rates}

The specific growth rate, $\mu$, for a fed-batch culture is expressed as:

$$
\mu=\frac{d(X V)}{(X V) d t}
$$

where $X, V$, and $t$ are cell density, culture volume, and time, respectively, and $\mu$ is determined from the slope of $\ln (X V)$ versus $t$. At each sampling point $t, V$ is determined from the sum of the initial broth volume, the volume of ammonium hydroxide, glycerol, and methanol added up to that time, minus the volume sampled. If the methanol concentration and $\mathrm{pH}$ are constant from toto $t$, the specific methanol $\left(\mathrm{n}_{\mathrm{MeOH}}\right)$ and ammonium $\left(\mathrm{n}_{\mathrm{NH}_{3}}\right)$ consumption rates, and the specific $\mathrm{BoNT} / \mathrm{A}\left(\mathrm{H}_{\mathrm{c}}\right)$ production rate, $r$, are expressed as (Katakura et al., 1998; Omasa et al., 1992a,b)

$$
\begin{array}{rlr}
Q_{\mathrm{MeOH}} & =v_{\mathrm{MeOH}} \int_{t_{0}}^{t}(X V) d t, & 2 \\
Q_{\mathrm{NH}_{3}} & =v_{\mathrm{NH}_{3}} \int_{t_{0}}^{t}(X V) d t, & 3 \\
J & =\rho \int_{t_{0}}^{t}(X V) d t, & 4
\end{array}
$$

where $Q_{\mathrm{MeOH}}$ and $Q_{\mathrm{NH}}$ are the total amount of methanol and ammonium consumed, respectively, and $J$ is the total protein produced from to to $t$. $Q \mathrm{MeOH}$ and $Q_{\mathrm{NH}_{3}}$ are determined by measuring the amount of methanol and ammonium added to the system. If $\mu$ is constant from $t_{0}$ to $t$, and, $X=X_{0}$ and $V=V_{0}$ at $t=t_{0}$, the following equations are obtained:

$$
\begin{gathered}
X V=X_{0} V_{0} e^{\mu\left(t-t_{0}\right)}, \\
\int_{t_{0}}^{t}(X V) d t=\left(X V-X_{0} V_{0}\right) / \mu .
\end{gathered}
$$

When Eq. (6) is combined with Eqs. (2) and (3), $\mathrm{n}_{\mathrm{MeOH}}$ and $\mathrm{vNH}_{3}$ are obtained from the slope of $Q_{\mathrm{MeOH}}$ versus $\left(X V-X_{0} V_{0}\right) / \mu$ and $Q_{\mathrm{NH}_{3}}$ versus $\left(X V-X_{0} V_{0}\right) / \mu$, respectively. $J$ is determined from

$$
J=\alpha(X V)-\alpha_{0}\left(X_{0} V_{0}\right), \quad 7
$$

where $a$ is the BoNT/A $\left(\mathrm{H}_{c}\right)$ content in the cells, as determined by ELISA, and $\mathrm{a}=\mathrm{a}_{0}$ at $t=t_{0}$. If $\mathrm{a}$ is constant during the fed-batch culture at a constant $\mu$ from to to $t$, Eq. (7) becomes

$$
J=\alpha\left(X V-X_{0} V_{0}\right)
$$

When Eqs. (4), (6), and (8) are combined, $p$ is

\section{MODELING OF THE FED-BATCH GROWTH}

A CSTR or exponential fed-batch culture can operate as a chemostat when the substrate feed concentration, $S_{\mathrm{f}}$, satisfies the following equation (Blanch and Clark, 1996):

where $Y_{X / S}$ is the observed yield of biomass to substrate. Both $Y_{X / S}$ and $S$ are dependent upon the desired $\mu$ and the type of substrate,

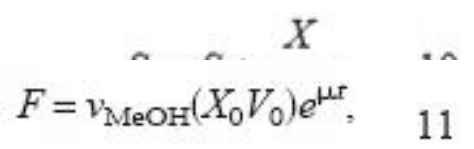

so $X$ is decided by $S_{\mathrm{f}}$ for a desired $\mu$. Since the maximum $X$ is limited to a certain level based on a given medium and fermentor design, i.e., oxygen supply, heat transfer, etc., the maximum $S_{\mathrm{f}}$ is also limited. It is proposed to model the fed-batch culture as a quasisteady state system, where $\mu$ an $S$ are constant, and $X$ varies within a limited range. This is possible if the biochemical activities of the cell do not vary significantly over the range of the cell densities being studied, then $\mu, n$, and $r$ will be constant. Therefore, a quasi-steady state will be defined as a growth condition where $X$ varies while $\mu, \mathrm{n}, \mathrm{r}$, and $S$ are constant within an experimental range of cell densities. Maintaining a constant $\mu$ is essential for attaining a quasisteady state. $\mu$ is a function of $S$, and $S$ can be maintained constant over a range of 1-30 g/L using a methanol sensor. When the methanol concentration is below the sensor's limit of detection, an alternative means of maintaining a constant $\mu$ is required. In this case, the methanol feed rate $(F)$ varies exponentially to maintain a constant $\mu$ using the following equation:

where $X_{0}$ is the cell density and $V_{0}$ is the broth volume when initiating the feed profile ( $t 40$ ). Once $\mu \mathrm{m}$ and $\mathrm{n}_{\mathrm{MeOH}, \mathrm{m}}$ have been determined empirically under methanol excess conditions, $\mathrm{n}_{\mathrm{MeOH}}$ is estimated for a desired $\mu$ by the following equation:

Eq. (12) is based on an assumption that $Y_{X / S} 4 \mu \mathrm{m} / \mathrm{n}_{\mathrm{MeOH}, \mathrm{m}}$ and is independent of $\mu$ and that the maintenance coefficient is negligible. This assumption is false, but it allows for an initial estimation of

$$
v_{\mathrm{MeOH}}=\mu v_{\mathrm{MeOH}, \mathrm{m}} / \mu_{\mathrm{m}} \cdot 12
$$

$\mathrm{n}_{\mathrm{MeOH}}$ Eq. (12) will be revised later to give the true relationship between $\mu$ and $\mathrm{n}_{\mathrm{MeOH}}$. When Eq. (12) is substituted into Eq. (11), F is estimated to deliver a constant desired $\mu$. Although the actual values of $\mu$ and $\mathrm{n}_{\mathrm{MeOH}}$ will differ from the estimated values, it is only important that they are constant. If $\mu$ and $\mathrm{n}_{\mathrm{MeOH}}$ are constant, a quasi-steady state is attained. Once the values of $S, \mathrm{n}_{\mathrm{MeOH}}, \mathrm{n}_{\mathrm{NH}}$, and $a$ in the quasisteady state with different desired $\mu$ have been determined by using either limited or excess feeding, an unstructured growth model which describes the relationships between $\mu$ and $S$, $\mathrm{n}_{\mathrm{MeOH}}$, and $\mu$, and $\mathrm{n}_{\mathrm{NH}_{3}}$ and $\mu$ can be established. The production model, which describes the relationship between $\mu$ and $a$ or between $\mu$ and $r$, is also achieved. From these two models all of the parameters related to growth and production can be predicted.

\section{RESULTS AND DISCUSSION}

Prior to this work, optimization of the methanol feeding strategy was viewed as empirical, following the standard procedure using either the D.O. spike method of methanol feeding (Brierley et al., 
1990) or preprogrammed linear feed rates (Stratton et al., 1998). Even though the D.O. spike method was used to successfully produce protein, the method is inconvenient and subjects a highcell density culture to changes in methanol feeding during D.O. spikes. The standard procedure is to reach a certain methanolfeeding rate, i.e., $11 \mathrm{~mL} / \mathrm{L} / \mathrm{h}$ and maintain this rate for the duration of the fermentation, which could sometimes be 36-70 h. Thus, as the biomass increased, the amount of methanol being fed per unit cell mass was decreasing. Since the production of recombinant protein and growth are regulated by the same type of promotor, our approach was to develop a model that coupled growth rate to product formation.

\section{Establishing the Growth Model}

\section{Methanol-Nonlimited Cultures}

To determine the growth characteristics of the culture when meth nol is in excess, fermentations were performed with $S$ between 2.0 and $30.0 \mathrm{~g} / \mathrm{L}$. The methanol concentrations were maintained at the desired levels throughout the fermentations with only minor fluctuations. Exponential growth was maintained at all levels of methanol, and this demonstrates that a quasi-steady state was maintained. As the $S$ increased, $\mu$ decreased, which shows the

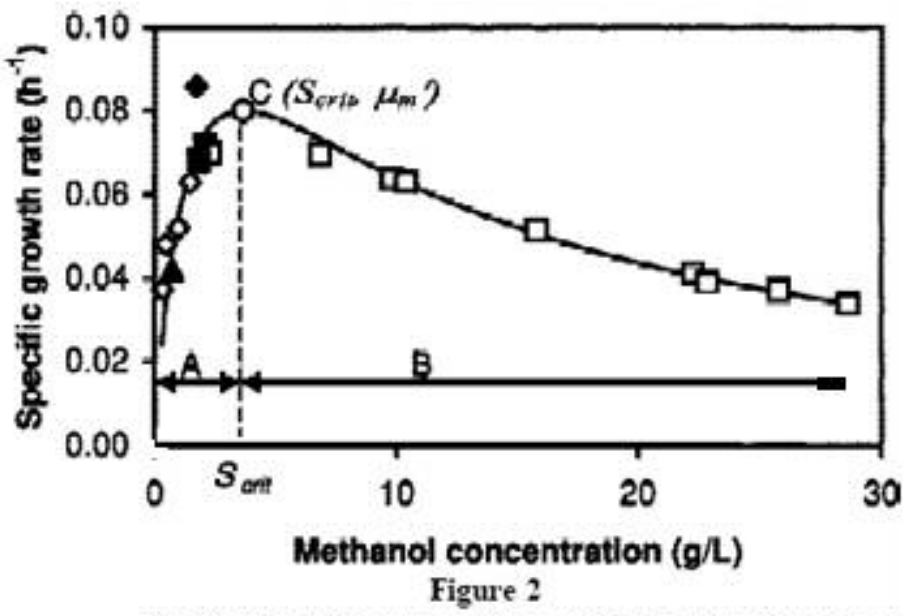

Relationship between specific growth rate and methanol cor: centration ( $\square$ ) Methanol non-limited cultures; $(\diamond)$ methanol-limited cul tures; ( $\bullet, \mathbf{\Delta}$ ) cultures of $P$. pastoris wild type Y-11430, host strai GS115 his ${ }^{-}$and GS115 his ${ }^{*} \mathrm{BONT} / \mathrm{E}\left(\mathrm{H}_{c}\right)$ clone, respectively.

inhibitory

$$
\begin{array}{rlrl}
v_{\mathrm{MeOH}} & =0.84 \mu+0.0071, & & 16 \\
v_{\mathrm{NH}_{3}} & =0.14 \mu . & 17
\end{array}
$$

The true yield of biomass and the maintenance coefficient, $Y_{X / S, t}$ and $m$ with respect to methanol and ammonium, were $Y_{X / \mathrm{MeOH}, \mathrm{t}} 4$ $1.19 \mathrm{~g} \mathrm{WCW} / \mathrm{g} \mathrm{MeOH}, m_{\mathrm{MeOH}} 40.0071 \mathrm{~g} \mathrm{MeOH} / \mathrm{g} \mathrm{WCW} / \mathrm{h} ; Y_{X / \mathrm{NH}}$ ,t $47.14 \mathrm{~g} \mathrm{WCW} / \mathrm{g} 28 \% \mathrm{NH}_{3}, m_{\mathrm{NH}_{3}} 40$, respectively. Substitution of Eq. (16) into Eq. (11) results in the following equation:

$$
F=(0.84 \mu+0.0071)\left(X_{0} V_{0}\right) e^{\mu t},
$$

which provides the corrected value of $F$ for a methanollimited fedbatch culture at a constant $\mu$. The following equations (19-24) were derived on thebasis of the feeding strategy described by Eq. (18). In this simulation, $\mu<\mu_{\mathrm{m}} 840.08 \mathrm{~h}-1, S<3.65 \mathrm{~g} / \mathrm{L}$, and $X<450 \mathrm{~g}$ WCW/L which was found to be the maximum $X$ that the medium of BSM supplemented with PTM1 trace salts can support in a quasi-steady state.

$$
\begin{aligned}
& X V=\left(X_{0} V_{0}\right) e^{\mu t}, \\
& V_{\mathrm{MeOH}}=(0.84 \mu+0.0071)\left(X_{0} V_{0}\right)\left(e^{\mu t}-1\right) / 0.79 \mu \\
& V_{\mathrm{NH}_{3}}=0.14\left(X_{0} V_{0}\right)\left(e^{\mu t}-1\right) / 0.9, \\
& V=V_{0}+V_{\mathrm{MeOH}}+V_{\mathrm{NH}_{3}}, \\
& X=\mu X_{0} e^{\mu r} /\left[\mu+(1.22 \mu+0.009) X_{0}\left(e^{\mu t}-1\right)\right], \\
& S=f(\mu)\left(\text { rewritten } \mu=\frac{0.146 S}{S+1.5+S^{2} / 8.86}\right) .
\end{aligned}
$$

To confirm if the model is applicable to other strains, the fed-batch cultivation of $P$. pastoris wild type NRRL Y-11430, host strain GS115 his- (supplemented with $1 \mathrm{~g} / \mathrm{L}$ histidine) and a GS115 his+ $\operatorname{BoNT} / \mathrm{E}\left(\mathrm{H}_{\mathrm{c}}\right)$ clone were synthesized. The actual values of $S, \mu$, $\mathrm{n}_{\mathrm{MeOH}}$, and $\mathrm{n}_{\mathrm{NH}_{3}}$ were within experimental agreement with the prediction. Therefore, the model could be applied to all the $P$. pastoris Mut+ strains as a starting point, provided that protein expression does not significantly change the growth properties of the strain. It had been reported that the recombinant protein expression could change the strain bioactivities and make the substrate metabolism much different from the host strain (Katakura et al., 1998; Wong et al., 1998). In this case, the model should be modified on the basis of the individual protein properties.

\section{Yx/MeOH,obs and mMeOH During Inhibited Growth}

For fed-batch fermentations under inhibited growth $\left(S>S_{\text {crit }}\right)$, the

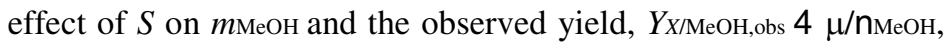
were determined. The relationship between $\mathrm{n}$ and $\mu$ during inhibited growth under quasi-steady state conditions was determined to be nonlinear, Fig. 4. It was observed that when $S$ increased, $\mathrm{X} / \mathrm{MeOH}$,obs decreased and $m \mathrm{MeOH}$ increased. From Eq. (16), the following equation was derived for calculating $Y_{X / \mathrm{MeOH}, \text { obs: }}$

$$
Y_{\mathrm{X} / \mathrm{MeOH}, \mathrm{obs}}=\mu / \nu=1.19-0.010 /(0.085+\mu) . \quad 25
$$

The broken line $\mathrm{A}$ in Fig. 4 shows the predicted values of

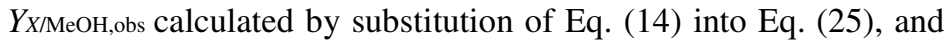
the broken line $\mathrm{B}$ is the $\mathrm{m \textrm {MeOH }}$ obtained in limited cultures. It was

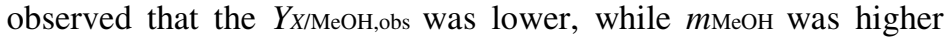
compared to limited cultures when $S>10 \mathrm{~g} / \mathrm{L}$, illustrating a lower efficiency for cell mass synthesis at higher $S$.

\section{Protein Production}

A typical protein production time course during a fed-batch culture is presented in Fig. 5. a reached a maximum after $12 \mathrm{~h}$ postinduction and remained constant or decreased slightly until the end of the quasi-steady state, which demonstrates that quasi-steady 
state for a or $r$ was not reached until $\mathrm{BoNT} / \mathrm{A}\left(\mathrm{H}_{\mathrm{c}}\right)$ inside the cells reached a maximum. After $X$ reached 400-450 g WCW/L, a started to decrease quickly, which confirmed the assumption that quasi-steady state exists within a certain range of $X$. The produc tion

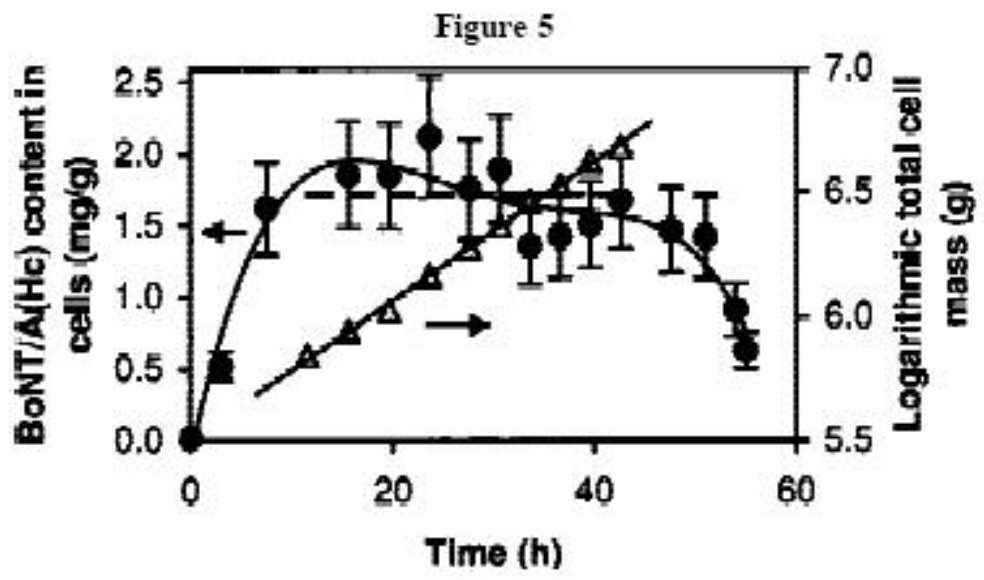

Typical time course of BoNT/A(H $\left.\mathrm{H}_{c}\right)$ production. Broken line average value of $\mathrm{BoNT} / \mathrm{A}\left(\mathrm{H}_{c}\right)$ content in cells during the quasi-steady state

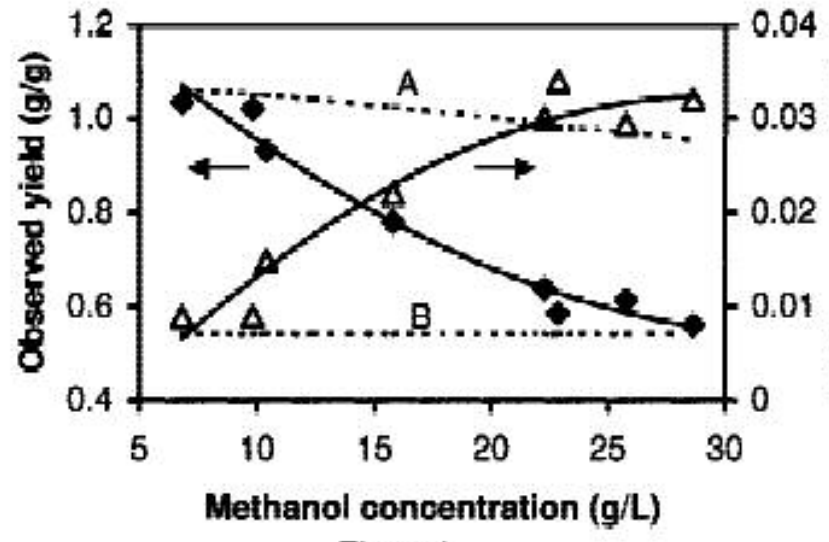

Figure 4

Effect of methanol concentration on observed yield of biomass and maintenance coefficient based on methanol in methanol-inhibited fermentations. (A) Observed yield calculated by substitution of Eq. 14 into Eq. 25. (B) Maintenance coefficient, $m(0.0071)$, in the methanol-limited cultures.

level, a, shown in Fig. 6 is an average value (n 4 8-10) during this quasi-steady state, which is indicated by the linear increase in $\ln (X V)$, Fig. 5. The effect of methanol concentration on a is presented in Fig. 6, where a critical specific growth rate $\mu_{c} 40.0267$ h-1 (at $\left.S 4 S_{1} 40.34 \mathrm{~g} / \mathrm{L}\right)$ produced a maximum BoNT/A $\left(\mathrm{H}_{\mathrm{c}}\right)$ per cell mass, $\mathrm{am}$, of $1.72 \mathrm{mg} \operatorname{BoNT} / \mathrm{A}\left(\mathrm{H}_{\mathrm{c}}\right) / \mathrm{g}$ WCW. Using Eq. (9), $r$ was calculated for each $\mu$ and is plotted in Fig. 6. The maximum specific product formation rate, $r_{\mathrm{m}}$, is $0.082 \mathrm{mg} / \mathrm{g} \mathrm{WCW} / \mathrm{h}$ when $\mu$ $4 \mu_{\mathrm{m}} 40.0709 \mathrm{~h}-1$ (at $S 4 S_{2} 42.1 \mathrm{~g} / \mathrm{L}$ ). Imbalances of energy supply for growth and production is usually considered to be the reason that $\mu$ affects a or $r$ (Chim-Anage et al., 1991; Shioya, 1992). There are two strategies for optimizing $\operatorname{BoNT} / \mathrm{A}\left(\mathrm{H}_{\mathrm{c}}\right)$ production depending on oxygen transfer capabilities. If the fermentation system has limited oxygen transfer capabilities the objective is to grow the cells to a pre-induction condition of $X 4$ $X_{0}, V 4 V_{0}$, where $J_{0} 40$ and $t 40$. The culture is induced for as long as $\mu 4 \mu_{\mathrm{m}} 40.0709 \mathrm{~h}-1\left(t_{\mathrm{f}}>12 \mathrm{~h}\right)$ is maintained. Integration of Eq. (4) based on these conditions results in an expression for $J_{\mathrm{m}}$.
$J_{\mathrm{m}}=\mathrm{r}_{\mathrm{m}} \sim X_{0} V_{0} ! e \mathrm{mmtf} / \mu_{\mu} .(26)$

For the second case, the syste $\mu$ is defined by the limitation of the media, i.e., final cell mass. The media describe in this work will support growth up to $450 \mathrm{~g} \mathrm{WCW/L}$. The objective is to optimize conditions so that once cell mass reaches a maximum that all of the cells contain the maximum amount of product. $J_{\mathrm{m}}$ is achieved

$$
\begin{gathered}
\text { when } \mu=\mu_{\mathrm{c}} \text { : } \\
J_{\mathrm{m}}=\alpha_{\mathrm{mr}} X_{\mathrm{f}} V_{\mathrm{f}} \quad 27
\end{gathered}
$$

The constraints on the system for maximum production of $\mathrm{BoNT} / \mathrm{A}\left(\mathrm{H}_{\mathrm{c}}\right)$ are an induction time of $12 \mathrm{~h}$, final cell mass of 450 $\mathrm{g} / \mathrm{L}$ and $\mu 4 \mu_{\mathrm{c}}$ during induction. Using Eqs. 19 through 23, we developed a spreadsheet that models the entire fermentation process and calculates all of system parameters, such as length of glycerol fed-batch phase and induction phase on the basis of growth rates, starting and ending volume, and all media requirements. From the model, we determined that the maximum yield of BoNT/

$\mathrm{A}\left(\mathrm{H}_{\mathrm{c}}\right)$ is $0.77 \mathrm{~g} / \mathrm{L}$ with a total fermentation time of $54 \mathrm{~h}$. This assumes the glycerol batch phase is $20 \mathrm{~h}$ (inoculum is $10 \%$ of the initial fermentation volume with an OD600 4 6) and that the fedbatch phase, which lasts $22 \mathrm{~h}$, reaches a cell density of $410 \mathrm{~g} / \mathrm{L}$ using a feed rate of $20 \mathrm{~g} / \mathrm{L} / \mathrm{h}(50 \% \mathrm{w} / \mathrm{v}$ glycerol $)$ and results in a final cell mass of $450 \mathrm{~g} / \mathrm{L}$ after a $12-\mathrm{h}$ methanol induction at $\mu_{\mathrm{c}}$.

\section{CONCLUSION}

An unstructured growth model was developed for a Mut+ strain of $P$. pastoris expressing $\mathrm{BoNT} / \mathrm{A}\left(\mathrm{H}_{\mathrm{c}}\right)$. The model describes the relationships between the specific growth rate and methanol concentration and between the specific growth rate and specific methanol and ammonium consumption rates. The maximum specific growth rate $(\mu)$ calculated from the model was $0.08 \mathrm{~h}-1$ at a methanol concentration of $3.65 \mathrm{~g} / \mathrm{L}$, while the realized maximum $\mu$ was $0.0709 \mathrm{~h}-1$ and maximum specific methanol consumption rate was $0.0682 \mathrm{~g} / \mathrm{g} \mathrm{WCW} / \mathrm{h}$. When the effect of methanol concentration on specific growth rate was investigated, it was determined that above a methanol concentration of $3.65 \mathrm{~g} / \mathrm{L}$ the cultured exhibited substrate inhibited and followed an uncompetitive inhibition model. The results from this study showed that there is an optimum rowth rate for optimum product formation of BoNT/ $\mathrm{A}\left(\mathrm{H}_{\mathrm{c}}\right)$. It was determined that $\mathrm{am}_{\mathrm{m}}$ reached a maximum of $1.72 \mathrm{mg} / \mathrm{g}$ wet cell mass when $\mu 4 \mu_{\mathrm{c}} 40.0267 \mathrm{~h}-1$, and $r_{m} 40.082 \mathrm{mg} / \mathrm{g} \mathrm{WCW} / \mathrm{h}$ when $\mu 4 \mu_{\mathrm{m}} 40.0709 \mathrm{~h}-1$. It is interesting to note that maximum intracellular product yield, $\mathrm{am}_{\mathrm{m}}$, was reached at approximately one-third of the maximum growth 
rate. At this time, the authors realize that the optimum growth rate for $\mathrm{BoNT} / \mathrm{A}\left(\mathrm{H}_{\mathrm{c}}\right)$ formation is probably protein specific. Studies are in progress to test this model for other intracellular and secreted products.

\section{Nomenclature}

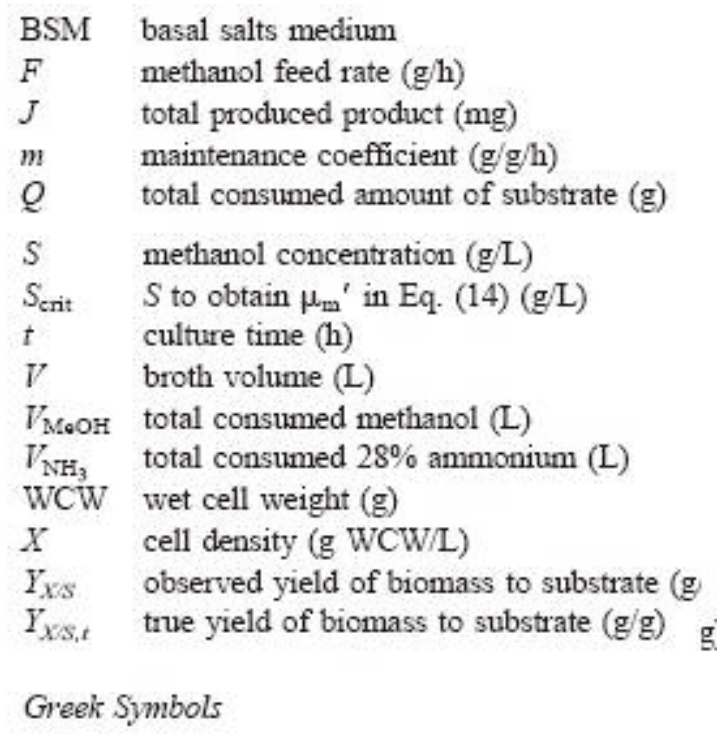

$\begin{array}{ll}\alpha & \text { product content in cells }(\mathrm{mg} / \mathrm{g}) \\ \mu & \text { specific growth rate }\left(\mathrm{h}^{-1}\right) \\ \mu_{\mathrm{c}} & \text { specific growth rate obtaining } \alpha_{\mathrm{m}} \\ \mu_{\mathrm{m}} & \text { maximum } \mu \text { in Eq. }(14)\left(\mathrm{h}^{-1}\right) \\ \nu & \text { specific substrate consumption rate }(\mathrm{g} / \mathrm{g} / \mathrm{h} \\ \rho & \text { specific product formation rate }(\mathrm{mg} / \mathrm{g} / \mathrm{h})\end{array}$

\section{Subscripts}

$\begin{array}{ll}0 & \text { at initial time } \\ \mathrm{f} & \text { at final time } \\ \mathrm{m} & \text { maximum } \\ \mathrm{MeOH} & \text { methanol } \\ \mathrm{NH}_{3} & 28 \% \text { ammonium } \\ \text { obs } & \text { observed } \\ \mathrm{t} & \text { true }\end{array}$

We thank John Regier for assisting in completing the ELISA assay of BoNT/A(Hc); Judy Lutgen, Jayne Stratton, and Dave Weier for helping with experiments. All of them are the members of BPDF at UNL. This research was financially supported by the United States Army Medical Research and Materiel Command

\section{References}

Blanch HW, Clark DS. 1996. Biochemical engineering. New York: Marcel Dekker. 702 p.

Brierley RA, Bussineau C, Kosson R, Melton A, Siegel RS. 1990. Fe mentation

development of recombinant Pichia pastoris expressing the heterologous gene: bovine lysozyme. Ann NY Acad Sci 589:350-362.

Byrne MP, Smith TJ, Montgomery VA, Smith LA. 1998. Purification, potency, and efficacy of the botulinum neurotoxin type A binding domain from Pichia pastoris as a recombinant vaccine candidate. Infect Immun 66:4817-4822.

Chim-Anage P, Shioya S, Suga K. 1991. Maximum histidine production by

fed-batch culture of Brevibacterium flavum. J Ferment Bioeng 71: 186190.
Clayton MA, Clayton JM, Brown DR, Middlebrook JL. 1995. Protective vaccination with a recombinant fragment of Clostridium botulinumneurotoxin serotype A expressed from a synthetic gene in Escherichiacoli. Infect Immun 63:2738-2742.

Couderc R, Baratti J. 1980. Oxidation of methanol by the yeast, Pichia pastoris. Purification and properties of the alcohol oxidase. Agric Biol Chem 44:2279-2289.

Cregg JM, Madden KR. 1988. Development of the methylotrophic yeast, Pichia pastoris, as a host system for the production of foreign proteins. In: Pierce G, editor. Development in industrial microbiology, vol. 29.

Amsterdam: Elsevier Science. p 33-41.

Cregg JM, Vedvick TS, Raschke WC. 1993. Recent advances in the expression

of foreign genes in Pichia pastoris. Bio/Technology 11: 905-910.

Cregg JM, Higgins DR. 1995. Production of foreign proteins in the yeast Pichia pastoris. Can J Bot 73:91-97.

Digan ME, Tschopp J, Grinna L, Lair SV, Craig WS, Velicelebi G, Siegel R, Davis GR, Thill GP. 1988. Secretion of heterologous proteins from the methylotrophic yeast, Pichia pastoris. In: Pierce G, editor. Development

in industrial microbiology, vol. 29. Amsterdam: Elsevier Science. p 5965.

Guarna MM, Lesnicki GJ, Tam BM, Robinson J, Radziminski CZ, Hasenwinkle

D, Boraston A, Jervis E, MacGillivray RTA, Turner RFB,

Kilburn DG. 1997. On-line monitoring and control of methanol concentration

in shake-flask culture of Pichia pastoris. Biotechnol Bioeng 56:279-286.

Hallis B, Fooks S, Shone C, Hambleton P. 1993. Characterization of monoclonal

antibodies to botulinum type A neurotoxin. In: DasGupta BR, editor. Botulinum and tetanus neurotoxins. New York: Plenum Press. p 433-436. Katakura Y, Zhang W, Zhuang G, Omasa T, Kishimoto M, Goto Y, Suga K. 1998. Effect of methanol concentration on the production of human b2-glycoprotein $I$ domain $V$ by a recombinant Pichia pastoris: a simple system for the control of methanol concentration using a semiconductor gas sensor. J Ferment Bioeng 86:482-487.

Lamanna C. 1959. The most poisonous poison. Science 130:763-772. Laroche Y, Storme V, De Meutter J, Messens J, Lauwereys M. 1994. High level secretion and very efficient isotopic labeling of tick anticoagulant

peptide (TAP) expressed in the methylotrophic yeast, Pichia

pastoris. Bio/Technology 12:1119-1124.

Omasa T, Ishimoto M, Higashiyama K, Shioya S, Suga K. 1992a. The enhancement of specific antibody production rate in glucose- and glutamine-

controlled fed-batch culture. Cytotechnology 8:75-84.

Omasa T, Higashiyama K, Shioya S, Suga K. 1992b. Effects of lactate concentration on hybridoma culture in lactate-controlled fed-batch operation. Biotechnol Bioeng 39:556-564.

Shimizu H, Kozaki Y, Kodama H, Shioya S. 1999. Maximum production strategy for biodegradable copolymer $\mathrm{P}(\mathrm{HB}-\mathrm{co}-\mathrm{HV})$ in fed-batch culture of Alcaligenes eutrophus. Biotechnol Bioeng 62:518-525.

Shioya S. 1992. Optimization and control in fed-batch bioreactors. In: Fiechter A, editor. Advances in biochemical engineering/biotechnology, vol. 46. Berlin: Springer. p 111-142.

Stratton J, Chiruvolu V, Meagher M. 1998. High cell-density fermentation. In: Higgins DR, Cregg JM, editors. Methods in molecular biology, vol. 103. Totowa, NJ: Humana Press. p 107-120.

Tschopp JF, Sverlow G, Kosson R, Craig W, Grinna L. 1987. High-level secretion of glycosylated invertase in the methylotrophic yeast, Pichia pastoris. Bio/Technology 5:1305-1308.

Uchiyama K, Ohtani T, Morimoto M, Shioya S, Suga K, Harashima S, Oshima Y. 1995. Optimization of rice a-amylase production using temperature-sensitive mutants of Saccharomyces cerevisiae for the PHO regulatory system. Biotechnol Prog 11:510-517.

Van der Klei IJ, Bystrykh LV, Harder W. 1990. Alcohol oxidase from Hansenula polymorpha CBS 4732. Methods Enzymol 188:420-427. Wong HH, Kim YC, Lee SY, Chang HN. 1998. Effect of post-induction nutrient feeding strategies on the production of bioadhesive protein in 
Escherichia coli. Biotechnol Bioeng 60:271-276. 